\title{
INHIBITION OF CATECHOL-O-METHYLTRANSFERASE BY HYDROXYBENZENES AND RELATED COMPOUNDS
}

\author{
KEISUKE HATTORI, MASAKO MATSUURA, \\ MOTOHATSU FUJIWARA AND KIRO SHIMAMOTO \\ Department of Pharmacology, Faculty of Medicine, Kyoto University, Sakyo-ku, Kyoto \\ Received for publication November 15, 1968
}

The inhibitory action of 1,2,3-trihydroxybenzene (pyrogallol) on the activity of catechol-O-methyltransferase (COMT) is well known (1-4). Recently, 1, 3, 5,-trihydroxybenezene (phloroglucinol) and 2, 4, 6-trihydroxy-1-propiophenone (THPP) have been shown to exert spasmolytic action in experimental animals and to relieve spastic disorders of the urinary tract and biliary ducts in patients (5-10). Comparing the relative effects of trihydroxybenzenes on the smooth muscle organs, Inoue and associates (11-13) have found that these compounds possess catecholamine-like actions and potentiate the cffect of catecholamines. Therefore, it is expected that phloroglucinol and THPP also inhibit the COMT activity. In the present experiments, the effects of phenol, phenolic ethanolamines, dihydroxybenzenes, trihydroxybenzenes and related compounds on the COMT activity of rat liver were studied in vitro.

\section{METHODS}

\section{Preparation of COMT from ral liver}

Male Wistar rats weighing 200 to $250 \mathrm{~g}$ were fed on the commercial diet and given water ad libitum for one week. The animals were killed by head amputation, exsanguinated, and the livers were immediately removed and chilled. Livers were homogenized in 4 volumes of isotonic $\mathrm{KCl}$ and centrifuged at $100,000 \times \mathrm{g}$ for 1 hour. The soluble supernatant was stocked in a refrigerator at $-18^{\circ} \mathrm{C}$ until used as crude COMT preparation. 2. S-Adenosylmethionine as a methyl donor

S-Adenosylmethionine was isolated from yeast cultures which were incubated with methionine following the method of Stekol et al. (14). The S-Adenosylmethionine was 5 to 10 times more active than the commercial product as a cofactor for the GOMT. It was stored in vacuo until used.

\section{Assay of COMT}

Incubation: According to Axelrod and Tomchick (15), COMT activity was determined by measuring the amount of metanephrine formed from adrenaline. The incubation mixture contained $0.2 \mathrm{ml}$ of crude enzyme preparation, $0.15 \mu \mathrm{mole}$ of 1 -adrenaline d-bitartrate, 5 pmoles of magnesium chloride, 0.25 kmole of S-adenosylmethionine, 25

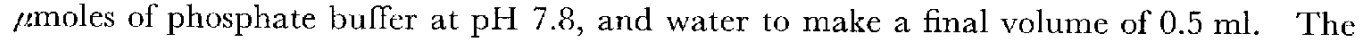


test compounds in final concentrations of $10^{-3}, 10^{-4}, 10^{-5} \mathrm{M}$ were added to the mixturcs. S-Adenosylmethionine was omitted from the reagent blank. The mixtures were incubated in a 40-ml glass-stoppered centrifugc tube at $37^{\circ} \mathrm{C}$ for 30 minutes. The reaction was stopped by addition of $0.25 \mathrm{ml}$ of borate buffer $(0.5 \mathrm{M}, \mathrm{pH} 10.0)$.

Extraction of metanephrine: Fifteen $\mathrm{ml}$ of isoamyl alcohol, washed previously with $1 \mathrm{~N}$ $\mathrm{NaOH}, 1 \mathrm{~N} \mathrm{HCl}$ and water, were added to the reaction mixtures, and metanephrine formed was extracted from the aqueous to the organic phase by agitation of the tube for 10 minutes. After centrifugation, $13 \mathrm{ml}$ of the organic phase was transferred to a $20 \mathrm{ml}$ glass-stoppered centrifuge tube containing $1.5 \mathrm{ml}$ of $0.1 \mathrm{~N} \mathrm{HGl}$. The tube was agitated for the return of metanephrine from the organic to the aqueous phase. Any residual amount of adrenaline was not extracted to the isomayl alcohol phase. The average recovery of metanephrine from the $\mathrm{HCl}$ phase was about $67 \%$ of that formed from adrenaline.

Estimation of metanephrine: The isoamyl alcohol was removed and $0.5 \mathrm{ml}$ of the $\mathrm{HCl}$ phase was transferred to a test tube and assayed for metanephrine according to a trihydroxyindole method (16). After addition of $3.3 \mathrm{ml}$ of $0.1 \mathrm{~m}$ phosphate buffer ( $\mathrm{pH} 7.2$ ) and $0.05 \mathrm{ml}$ of $1 \mathrm{M} \mathrm{NaOH}$, metanephrine in $\mathrm{HCl}$ was oxidized with $0.05 \mathrm{ml}$ of $0.02 \mathrm{M}$ iodine for 5 minutes, then tautomerized by adding $0.5 \mathrm{ml}$ of a mixture of $2 \%$ ascorbic acid and $5 \mathrm{~N} \mathrm{NaOH}(1: 9)$. The product was immediately detcrmined by the use of a spectrofluorometer (Hitachi, MPF-2) at the wave length of $517 \mathrm{~m} \mu$ after activation at $410 \mathrm{~m} \mu$. Faded blanks were the samples in which the ascorbic acid was added 5 minutes after the $\mathrm{NaOH}$. The difference between amount of metanephrine formed by incubation with and without S-adenosylmethionine was estimated as enzymatic O-methylation of adrenaline. Each experiment consisted of 3 to 5 observations.

\section{Agents tested}

$d l$-2-Amino-phenylethanol sulfate (Aldrich), phenol, $d l$-octopamine hydrochloride (Sigma), $d l-\alpha$-methyloctopamine hydrochloride (Aldrich), $l$-synephrine hydrochloride (Sigma), $l$-phenylephrine hydrochloride (Sigma), pyrocatechol, resorcinol, hydroquinone, pyrogallol, 1, 2, 4-trihydroxybenzene (1, 2, 4-THB, Takeda), phloroglucinol (Roussel), and THPP (Eisai) were tested.

\section{RESULTS}

The ability of the crude COMT preparation to methylate adrenalinc varied considerably according to the concentration of S-adenosylmethionine added to the incubation media. In the presence of $0.05 \mu$ mole of added methionine the conversion rate of adrenaline to metanephrine was about $29 \%$, while the corresponding value in the presence of $0.25 \mu$ mole of the methionine was $89 \%$ (corrected for the recovery of extraction of metanephrine formed).

Using $27.42 \mu \mathrm{g}(0.15 \mu \mathrm{mole})$ of adrenaline bitarirate as a substrate and $0.25 \mu \mathrm{mole}$ of S-adenosylmethionine as a methyl donor, the effects of compounds on the rat liver enzyme activity werc determined. Figs. 1-4 show the amounts of metanephrine formed in the presence of test compounds. $d l-2-A m i n o-1-p h e n y l e t h a n o l$ and phenol did not inhibit the 


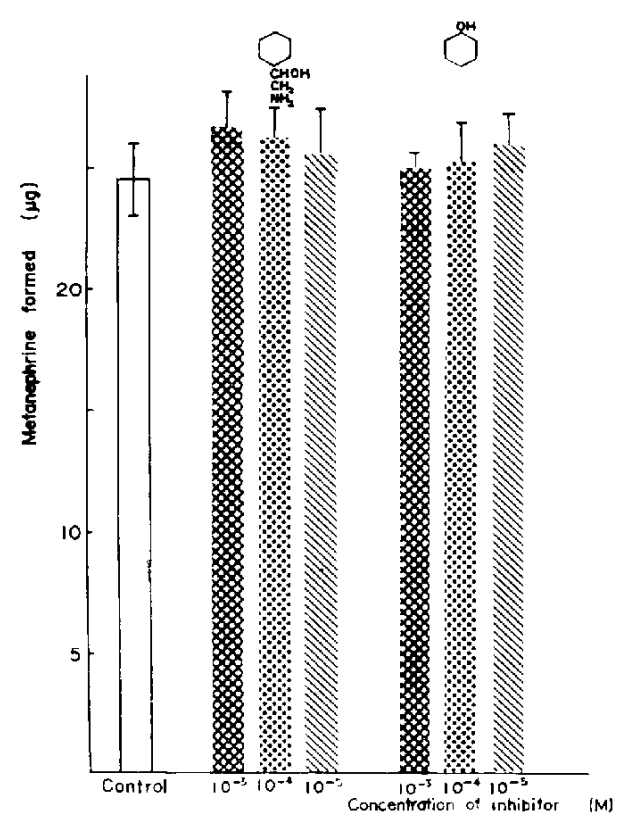

Fig. I. Effect of dl-2-amino-l-phenylethanol and phenol on rat liver COMT activity.

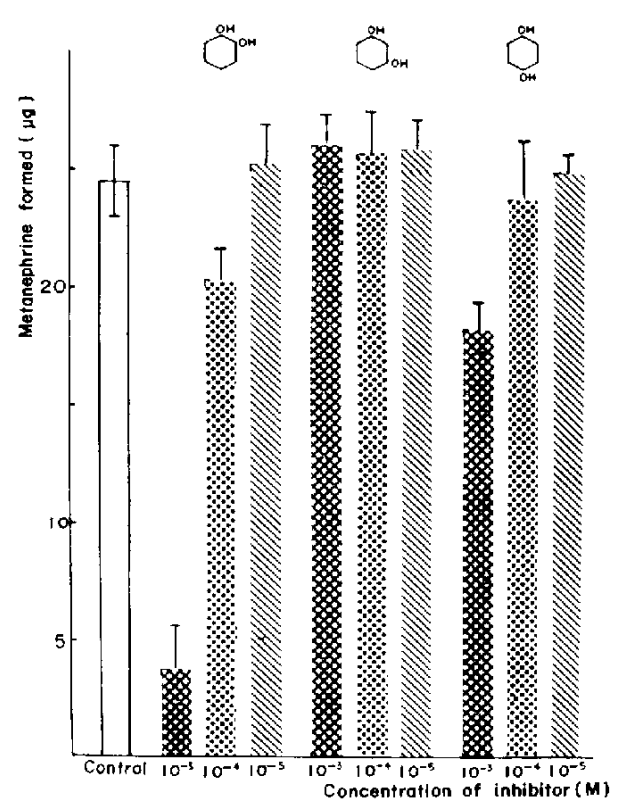

FIG. 3. Effect of pyrocatechol, resorcinol and hydroquinone on rat liver COMT activity.

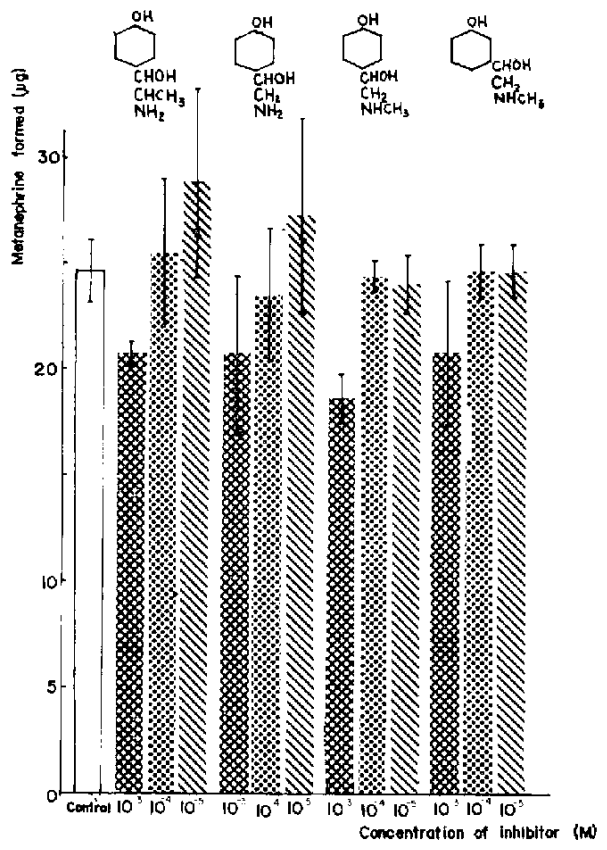

Fig. 2. Effect of $d l$ - $\alpha$-methyloctopamine, $d l$ octopamine, $l$-synephrine and $l$-phenylephrine on rat liver COMT activity.

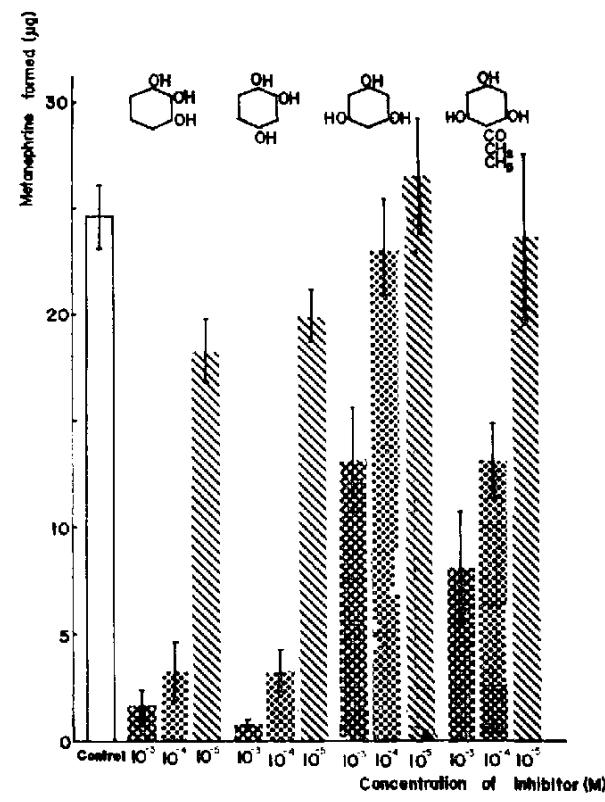

FIG. 4. Fffect of pyrogallo1, 1,2,4-THB, phloroglucinol and THPP on rat liver COMT activity. 
enzyme activity. Phenolic cthanolamincs such as $d l$-octopamine, $d l$ - $\alpha$-methyloctopamine, $l$-synephrine and $l$-phenylephrine slightly inhibited the enzyme activity only at a concentration of $10^{-3} \mathrm{M}$. Dihydroxybenzenes such as pyrocatechol and hydroquinone definitely inhibited the enzyme activity, but resorcinol was without cffect at all concentrations tested. Trihydroxybenzenes, particularly pyrogallol and 1, 2, 4-THB inhibited the COMT activity even at a low concentration of $10^{-5} \mathrm{M}$. Phloroglucinol and THPP showed weaker but definite inhibitory action on the COMT activity.

\section{DISCUSSION}

The present results show that the benzencs which possess two or three adjacent hydroxy groups in the ring inhibit to a various degree the activity of rat liver COMT. Phloroglucinol and THPP also had the COMT inhibitory action in vitro. Pharmacological studies of phloroglucinol $(5,11,12)$ and THPP $(6,12,13)$ showed that these compounds relieve experimental spasms of biliary and urogenital tracts and that they potentiate the responses to exogenously administered catecholamines and to sympathetic nerve stimulation. In the smooth muscles of thesc organs there is abundant distribution of catecholamine-fluorescent nerve fibers (17). These facts suggest that trihydroxybenzenes exert the spasmolytic effect due to the inhibition of tissue COMT activity with a subsequent incease of sympathetic tone. However, studies were made on the liver enzyme, but not on the COMT of the smooth muscle organs themselves.

At present, there is no available information regarding the role of COM $\Gamma$ played in the inactivation of catecholamines in biliary and urogenital organs. Even if it is allowed that the COMT plays an important role in the metabolism of endogenous catccholamines, the exogenously administercd hydroxybenzencs must cross the cell membrane before they may attack the enzyme and exert the pharmacological actions. There is another possibility that the hydroxybenzenes exert the pharmacological actions by disturbing the membrane transport mechanism rather than inhibiting the COMT. Before correlating the spasmolytic action of hydroxybenzenes with the inhibition of tissue COMT, it is required to show the increase in level of the endogenous catecholamines and also the decrease in level of metanephrine and normetanephrine in these organs.

\section{SUMMARY}

The effects of hydroxybenzenes and related compounds on the activity of rat liver COMT were studicd in vitro. $d l$-Phenylethanolamine, phenol and resorcinol were without effect. Hydroxyphenylethanolamines and hydroquinone inhibited the enzyme activity only at a high concentration of $10^{-3} \mathrm{M}$. Pyrogallol and 1, 2, 4-THB showed the strongest inhibition of the enzyme. 'The effects of pyrocatechol, phloroglucinol and THPP were intermediate. A correlation between spasmolytic actions and COMT inhibition of hydroxybenzenes is discussed.

Acknowledgments: The authors wish to thank Prof. O. Hayaishi and Dr. Y. Nishizuka for their hclp in preparing the enzyme from rat liver, and Dr. Y. Shinagawa for his advice to use 1,2,4-THB. 


\section{REFERENCES}

1) Axelrod, J. And Laroche, J.M.: Science, N.Y. 130, 800 (1959)

2) BaCq, 7.M., Gosselin, L., Dresse, A. and Renson, J.: Science, N.Y. 130, 453 (1959)

3) Udenfriend, S., Crevei.ne, C.R., Ozakr, M., Daly, J.W. And Witkop, B.: Archs Biochem. Biophys. 84, 249 (1959)

4) Crout, J.R.; J. Pharmac. exp. Ther. 132, 269 (1961)

5) Cahen, R.: Archs int. Pharmacodyn. Thér. 138, 311 (1962)

6) Cahen, R. and Boucherle, A.: C. r. Séanc. Soc. Biol. 157, 112 (1963)

7) Debray, Git., Hardoun, J.-P., Vaille, Ch. and Ghariot, J.: Thérapie 18, 683 (1963)

8) Debray, Cir., De la Tour, J., Vaille, Cir., Rozé, Cl. and Souchard, M.: Thérapie 19, 1523 (1964)

9) Namik,, S. AND Fukushima, K.: Gendai no Rinsyo 1, 469 (1967) (in Japanese)

10) NaGamitsu, S.: Gendai no Rinsyo 1, 713 (1967) (In Japanese)

11) Inoue, S.: Gendai no Rinsyo 1, 212 (1967) (In Japanese)

12) Inoue, S.: Jap. J. Pharmac. 19, 224 (1969)

13) Inoue, S., Ishit, M. and Shimamoto, K.: Gendai no Rinsjo 1, 764 (1967) (In Japanese)

14) Stekol, J.A., Anderson, E.I, and Weiss, S.: J. biol. Chem. 233, 425 (1958)

15) Axelrod. J. And Tomchick, R.: J. biol. Chem. 233, 425 (1958)

16) Bertler, A., Ciarlsson, A. and Rosengren, E.: Clin. Chin. Acta 4, 456 (1959)

17) Fujtwara, M. and Mort, J.: To be published 